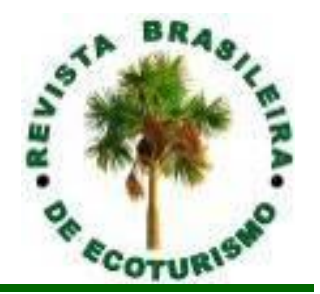

\title{
Public use and conservation of trails at the Parque Natural Municipal das Andorinhas, Ouro Preto, Brazil ${ }^{1}$
}

\section{Uso público e conservação: estudo das trilhas do Parque Natural Municipal das Andorinhas, Ouro Preto (MG)}

\author{
Simone Fernandes Machado, Ricardo Eustáquio Fonseca Filho, \\ Sandra Maria Antunes Nogueira
}

\begin{abstract}
Several categories of Protected Areas (PAs) established in Brazil allow for public use. However, the impacts resulting from tourist visitation activity in them are poorly researched and technically managed. The central question of the study is how the unplanned opening of trails for tourism purposes can impact the Parque Natural Municipal das Andorinhas (PNMA), a natural park, in Ouro Preto (MG, Brazil). The hypothesis is the understanding that the use of unplanned trails can impact the PA. In this sense, the objective of this work was to analyze nine trails used for tourist visitation at the PNMA. The research methodology included bibliographic and documentary research of the trails, their management, and environmental impacts; elaboration of a structured quali-quantitative form to analyze them; and fieldwork. As a result, it was observed that the main environmental characteristics of tourist interest are the observation of flora and fauna and watercourses; and the main impacts are fires, the irregular opening of trails, and deforestation. It is concluded that knowledge regarding the situation of the trails can help the PA management in their planning and conservation.
\end{abstract}

KEYWORDS: Environmental Sustainability; Nature Tourism; Environmental Impact; Heritage Conservation; Conservation Units.

RESUMO: Diversas categorias de Unidades de Conservação (UCs) instituídas no Brasil permitem o uso público. Entretanto, os impactos resultantes da atividade de visitação turística nessas áreas são pouco pesquisados e tecnicamente geridos. A questão central do estudo é como a abertura não planejada de trilhas para fins turísticos pode impactar o Parque Natural Municipal das Andorinhas (PNMA) em Ouro Preto (MG). Tendo como hipótese o entendimento de que a utilização de trilhas não planejadas pode causar impactos na UC. Neste sentido, o objetivo do presente trabalho foi o de analisar nove trilhas utilizadas para visitação turística do PNMA. A metodologia da pesquisa abrangeu pesquisa bibliográfica e documental das trilhas, seu manejo e impactos ambientais; elaboração de ficha qualiquantitativa estruturada para analisá-las; e trabalhos de campo nas mesmas. Como resultado, observou-se que as principais características ambientais de interesse turístico são a observação de flora e fauna e os cursos d'água; e os principais impactos são as queimadas, abertura irregular de trilhas e desmatamento. Conclui-se que o conhecimento da situação das trilhas pode auxiliar a gestão da UC no planejamento e conservação das mesmas.

PALAVRAS-CHAVE: Sustentabilidade Ambiental; Turismo de Natureza; Impacto Ambiental; Conservação do Patrimônio; Unidades de Conservação. 


\section{Introduction}

Conservation actions in Brazil developed progressively from the 20th century onwards, mainly after the 1970s, as a result of industrial advances, population increase, and because of new urban patterns and consequent processes of environmental degradation.

In this context, Permanent Preservation Areas (PPAs) and Protected Areas (PAs) were established. Both were created by federal laws, PPAs through the Forest Code, Federal Law no. 4,771 (BRASIL, 1965); and the PAs by Federal Law no. 9,985 (BRASIL, 2000) - which regulates the National System of Nature Conservation Units (in Portuguese Sistema Nacional de Unidades de Conservação da Natureza - SNUC).

While the first is restricted to forested or geologically unstable areas, with pre-established geographic boundaries, the latter has a greater scope, protecting various natural assets and with delimitation established through technical studies and popular consultation.

PAs are divided into two groups: Sustainable Use and Full Protection. The first ones aim to make the conservation of nature compatible with the sustainable use of a portion of its natural resources. The latter only admits the indirect use of their resources (BRASIL, 2000). In both, except for cases protected by law, activities of "public use" may be allowed. According to Magro (1999), this expression was adopted by official bodies as a term related to the management of protected natural areas in the country, representing those where visitation activities are allowed, with restrictions defined by the management plan and by the management of the PA.

One of the forms of public use is tourism, which according to the World Tourism Organization (WTO, 2001), "comprises the activities that people perform during their travels and they stay in places other than their usual surroundings, for a consecutive period of less than one year, for leisure, business or other purposes". Nonetheless,

The consequences of the large flow of people in the sensitive environments of the PAs make the planning of spaces, equipment, and tourist activities fundamental, to avoid damage to the environment, as well as to ensure the attractiveness of resources for future generations. In general terms, the impacts of tourism are discussed to identify the footprint left by the tourist, by tourism and its associated infrastructure, on the environment that was transformed into a destination (SANTANA, 2009, p.148).

The public use of the PA, as for recreation/in a touristic way, generates environmental impacts, and the severity depends on the ability of the environment to resist and recover. Therefore, it is up to the management, standardize and supervise acceptable limits in each area of the PA, to mitigate impacts (TAKAHASHI, 2004). Santana (Op cit.) pays attention to the 
fact that very few tourists generate negative impacts in a conscious and premeditated way, and usually collaborate when there is accessible information or code of conduct.

Trails are usually the first structural elements developed in PAs, generally, to access attractions, and therefore, frequently used by tourists. In the Parque Natural Municipal das Andorinhas (PNMA), a natural park in Ouro Preto, Minas Gerais (MG), nine trails present environmental changes due, in part, to visitation.

The large flow of visitors, combined with the lack of awareness of users, is causing an accumulation of garbage in areas of waterfalls and trails inside and outside the PA, in addition to the use and opening of new trails for sports such as motocross, which can enhance the erosive effects and drive away fauna (MYR, 2017, p. 786).

In this sense, the objective of this work is to these trails, used as access to the tourist attractions in the PNMA. The hypothesis that arises is that, when not planned and monitored, their use may go against the conservationist and environmental sustainability principles of the PA. And the relevance of the research lies in the search for mechanisms that help in the identification of impacts and in planning for the compatibility of visitation activities with the conservation goals of these places, thus ensuring the sustainability of their natural resources and improving the experience for the visitor.

\section{Theoretical Reference}

One of the most important initiatives for sustainable development was the Stockholm Conference (United Nations Conference on the Human Environment), in 1972. However, sustainable development only became the main issue of the environmental policy after the United Nations Conference on Environment and Development (Rio-92). On the occasion, the United Nations, through the Our Common Future report, published by the World Commission for the Environment and Development in 1987, established the concept of sustainable development, "it meets the needs of the present without compromising the ability of future generations to meet their own needs" (MIKHAILOVA, 2004, p. 26).

The environmental legislation in Brazil took shape in the 1960s. The new Forest Code dates from this period (BRASIL, 1965), a set of laws already concerned with the rational and balanced use of natural resources.

Initiatives before Rio-92 were important for public environmental policies in Brazil, such as the creation of the Special Secretariat for the Environment in 1973; Law No. 6,938, establishing the National Environmental Policy (BRASIL, 1981); and the Federal Constitution (BRASIL, 1988), which stated in its Article 225 that "everyone has the right to an ecologically balanced environment, imposing on the Public Power and the community the duty to defend and preserve it for the present and future 
generations". About a decade later, the SNUC regulated the creation of the PA.

In this context, there was a need for studies that would make the management of established PAs feasible. According to the SNUC Law (BRASIL, 2000), management is "every procedure aimed at ensuring the conservation of biological diversity and ecosystems". For Cifuentes, Izurieta, and Faria (2000, p. 105), "the management is considered effective when the set of actions undertaken allows to satisfactorily fulfill the objectives for which the protected area was created".

Part of the management of the PAs takes place through trails which, according to the ABNT (2008, p. 1), are "narrow lanes, usually unpaved and impassable for passenger vehicles". Until the 19th century, they were the main component of the land transport infrastructure of the peoples of the planet. An example of this is that "the bandeirantes used to stride the existing trails, left by natives in the region" (SILVA, 2016, p. 20). However, it is not possible to state that part of the PNMA trails dates to that time, but Vasconcelos (1974) affirms that some were opened by pioneers, who arrived at Morro de São João and founded the then named Vila Rica. "People, cargo and domestic animals moved through the trails" (ICMBio, 2018, p. 9), besides the emphasis given, in PAs, to their educational and recreational use (TAKAHASHI, 2004).

For Lechner (2006), trails are usually the first of the infrastructure elements developed whenever a new protected area is constituted, and this often occurs before planning. Leung and Marion (2001, p. 18) point out that they "can be created and maintained formally by management agencies or created informally by users". However, "such differences in the informal occurrence of trails have implications for their fragmentation effects, as well as for monitoring and management strategies" (LEUNG; PICKERING; COLE, 2012, p. 1).

In this sense, Eisenlohr et al. (2013, p. 418) consider that "negative impacts on biodiversity caused by ecotourism are aggravated by the fact that trails are usually treated only as a means of travel to natural tourist attractions, and do not receive appropriate conservation".

Thus, for their implementation, it is necessary to consider the following aspects:

a) highlighting and spreading the culture associated with the route; b) seeking to restore the traditional path as much as possible c) supporting the sustainable development of the environment; d) considering the natural resources and elements of the archaeological, cultural, and ethnographic historical heritage; e) the existence of support services along the way (accommodation, parking, accesses, traditional commerce, etc.); f) possible intercommunication with public transport networks; g) possible actions for the recovery and requalification of assets; h) suitable for all types of users; i) avoiding dangerous or risky routes; j) avoiding fragile natural areas and risks of fire (OLIVEIRA, 2007, p. 6-7). 
The trails can be classified in different ways, for example, "taking into account their function, extension, level of difficulty and resources used in their interpretation" (BRAGA, 2007, p. 125). A common misconception is that the implementation of trails does not influence the dynamics of the landscape and the ecosystem, due to their small dimensions. However, when in places more prone to degradation, under intensive use, and without management, they can compromise the general objectives of the PAs (KROEFF, 2010).

Soil degradation is defined by the Brazilian Association of Technical Standards (ABNT, 1989, p. 6), as the "adverse change in the characteristics of the soil concerning its various possible uses, both those established in planning and potential ones".

Activities on an interpretive trail can have their objectives broken down into points related to environmental experience, perception, and interpretation, with the main objective of recovering the meaning and value of the person-environment interaction. "For this reason, environmental interpretation activities can be developed and mobilized based on the desire to re-educate actions regarding the environment, providing changes in actions and emotions" (SILVA; BOZELLI; FREIRE, 2018, p. 2).

Interpretive trails, therefore, are examples of formative and informative activities, which provoke new processes of adaptation and assimilation, related to the development of structured experiences and knowledge about the environment. (PAIVA; FRANÇA, 2007, p. 102).

In the PNMA, there are 11 formal accesses, consisting of nine trails (totaling about $10 \mathrm{~km}$ ) and two roads (Table 1), located mostly in the centersouth region of the Park (Figure 1).

Table 1: Trails intended for public use in the PNMA.

\begin{tabular}{lc} 
Name of the Trail & $\begin{array}{c}\text { Approximate distance from the trail to } \\
\text { the administrative headquarters of the } \\
\text { PA }\end{array}$ \\
\hline Trilha Cachoeira das Andorinhas & $550 \mathrm{~m}$ \\
\hline Trilha da Cachoeira dos Pelados & $650 \mathrm{~m}$ \\
\hline Trilha da Cachoeira Véu da Noiva & $1,100 \mathrm{~m}$ \\
\hline Trilha do Baú & $690 \mathrm{~m}$ \\
\hline Trilha do Mirante Pedra do Jacaré & $525 \mathrm{~m}$ \\
\hline Trilha do Poço da Folhinha & $2,450 \mathrm{~m}$ \\
\hline Trilha do Poço do Baú & $600 \mathrm{~m}$ \\
\hline Trilha do Vermelhão & $2,800 \mathrm{~m}$ \\
\hline Trilha dos Setores de Escalada & $650 \mathrm{~m}$ \\
\hline
\end{tabular}

Source: research data (2019). 


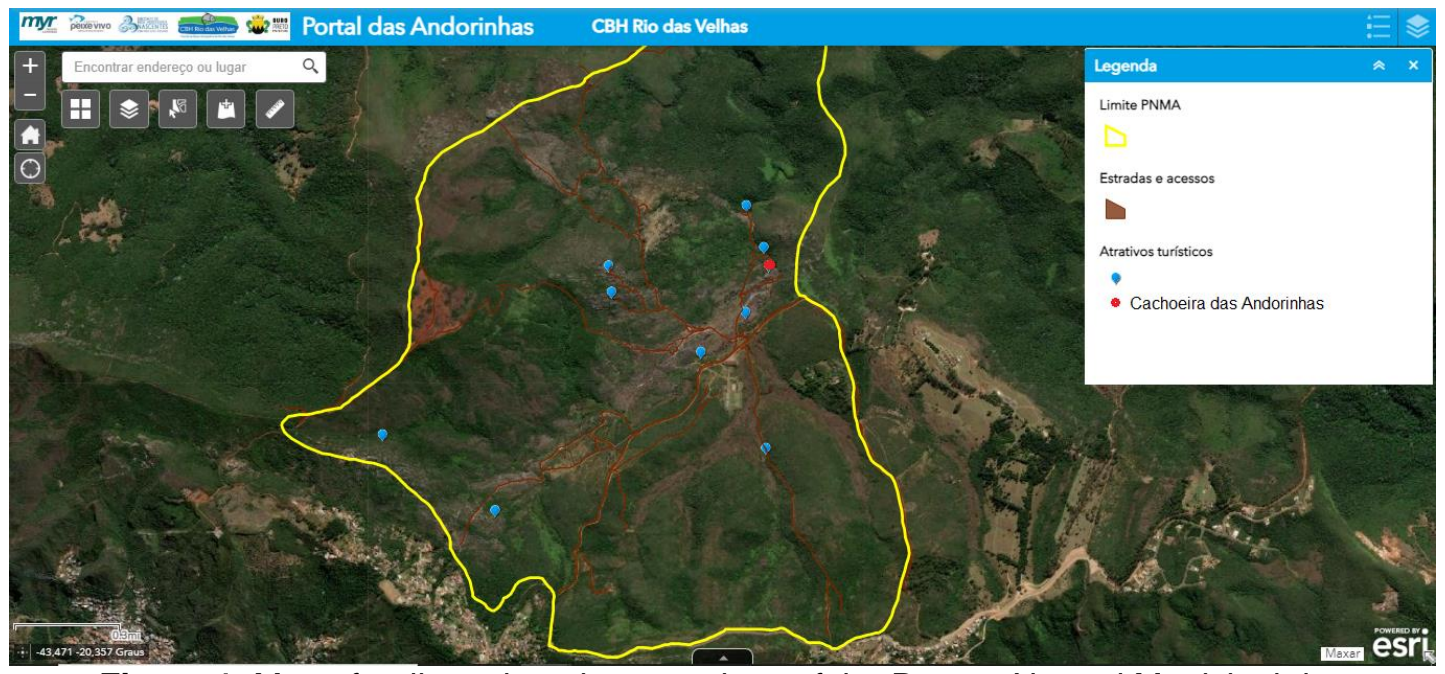

Figure 1: Map of trails and tourist attractions of the Parque Natural Municipal das Andorinhas, Ouro Preto, Brazil.

Source: modified from the Andorinhas website (2021).

The PA was created in 1968 (OURO PRETO, 1968) for the ecological preservation of the area where part of the high springs from the Velhas River meet, one of the main tributaries of the São Francisco River. Its protection is of the integral type. Its area and name are regulated by Law No. 305 (OURO PRETO, 2005). It has an area of 575 hectares, managed by the Municipal Secretariat for the Environment, and is open to visitation for other natural attractions, in addition to the trails - e.g., Pedra do Jacaré and Cachoeira das Andorinhas - besides infrastructure and services, such as a center for visitors and environmental monitors, respectively.

The success of the management of protected areas is based on organizing and controlling; obtaining data and properly processing information about the area and its surroundings; in addition to planning. "Whether of an environmental, social, economic or cultural nature, data and information must also be prioritized, systematized, monitored, always accessible, and its users qualified to apply them" (CHAPE; SPALDING; JENKINS, 2008, p.125).

Given that the PNMA receives an average of 16 thousand visitors per year (MACHADO, 2013), it is an area of relevant ecological interest - home to elevated springs of the Velhas River - with no control over the visitation via every access to the PA. There may be an imbalance in the geographicalecosystem equilibrium. Thus, this study analyzed the current situation of open trails for public use and qualified the main existing impacts, to support planning and management actions of this PA.

\section{Materials and methods}

At first, we sought to conduct a literature review, digital and documentary, of the themes "trails", "trail management" and "environmental impacts on trails", in databases such as Google Scholar, Scielo, Scopus, and Databases of Theses and Dissertations from Universities. 
The choice of the object of study was because the PNMA is a PA open to visitation, and presents trails spontaneously created by the local population, making it a relevant area for investigating the possible impacts of visitation, by natives or tourists.

To assess the state of conservation of the areas used by visitors, the main procedure was the structuralist (LAKATOS, 2003, p. 111), as the state of conservation of the trails was compared to more suitable existing models pointed out by the literature.

A structured quali-quantitative field form was created, consisting of 18 multiple-choice/descriptive questions to survey aspects such as zoning (RUSCHMANN, 1997); type, length, format, and degradation of the trail (ANDRADE, 2003; SALVATI, 2003); terrain conditions, severity and intensity of physical effort (ABNT, 2008); biome, vegetation, water resources and air quality (IBGE, 2004); soils (EMBRAPA, 1997; LECHNER, 2006); slope (IBGE, 2015); and relief (CHRISTOFOLLETI, 1974).

Regarding fieldwork, the nine existing trails in the PNMA used in the visitation activities were analyzed in March 2020, with the first author filling out the field forms. The type of field research used to evaluate the trails was, according to Lakatos (Op cit.), qualitative and descriptive, as it sought to verify the origin of the hypotheses, describe phenomena observed qualitatively, and present them quantitatively.

In the survey of the state of conservation and characterization of the trails, the observational method was used, at first, through structured and non-participant systematic observation (GIL, 2008), in which the occurrence of certain characteristics, that were registered in the fieldwork records, suggest some kind of degradation.

The forms were applied to each of the nine consolidated access trails, later the data obtained were tabulated and systematized in the Microsoft Office Excel software, version 2010.

\section{Analysis and Discussion of Results}

The needs arising from analyzes of environmental impacts in the 1970s gained strength with the enactment of the National Environmental Policy (BRASIL, 1981), which listed precise instruments for its implementation, relying on their effectiveness for integrated environmental management. Among them, there is environmental zoning, "whose importance is highlighted since it aims to support planning and ordering processes for the use and occupation of the territory, as well as the use of environmental resources" (MILARÉ, 2011, p. 1).

Zones can be defined according to the types of use or destination allowed. According to Ruschmann (1997, p. 129-130), natural areas are divided into Intangible, Primitive, Intensive Use, Historical-cultural, Natural Recovery, and Special Use Zones.

In turn, the PNMA Management Plan (MYR, 2017) established the following ones: Intangible (ZI), Primitive (ZP), Conflicting Use (ZUC), 
Recovery (ZR), Extensive Use (ZUE), intensive use (ZUI), special use (ZUE) and temporary occupation (ZOT).

It is possible to note the inclusion of two zoning categories, in relation to Ruschmann (1997), the Conflicting Use zone, which refers to the area with the presence of a public utility enterprise - in this case, an electric power transmission line; and the Temporary Use zone, in which the presence of properties that have not yet been expropriated is observed. Both are areas of anthropogenic pressure that pose risks to the conservation of the PA.

Of the trails inventoried in the Management Plan (MYR, 2017), $36.36 \%$ are in $\mathrm{ZUI}, 27.27 \%$ in $\mathrm{ZUE}, 18.18 \%$ in $\mathrm{ZP}$ and $\mathrm{ZI}$. It is noteworthy that the trails are in predominantly fragile areas (63.63\%): ZP, ZI, and ZUE, and therefore need more attention in planning and maintenance, to minimize negative impacts on the environment. In state of alert, are the trails of Baú, Vermelhão, Poço do Baú, Cachoeira dos Pelados, Cachoeira Véu da Noiva, Poço da Folhinha and Setores de Escalada. The latter is under special attention because, according to a study by Nunes (2021), there are climbing routes along the trail with loose blocks, causing a risk of collapse and, consequently, accidents to hikers and/or climbers.

Looking more closely at the trails, concerning length, they can be divided into short-distance ones, called interpretive trails; or long-distance ones, which enhance the experience of the visitor who seeks to move through large wild spaces, such as crossing trips through the region (ANDRADE, 2003). "In English-speaking countries, the terms hiking (short distances) and trekking (long distances, overnight) are used for walking activities, for leisure in natural areas and mountains" (SILVA, 2016, p. 47). Thus, all PNMA trails can be considered as of the trekking type.

NBR 15505-2 (ABNT, 2008) describes a classification for trails, composed of four criteria: a) severity of the environment; b) route orientation; c) terrain conditions; d) intensity of physical effort. Each trail must be evaluated for each of the criteria.

The severity of the environment criterium is described as "dangers and other difficulties arising from the natural environment, such as temperature, rainfall, risks of falls, ease of rescue, among others, that can be found along the route" (Op cit., p. 3). The route orientation criterium is the "degree of difficulty for orientation, such as the presence of signs, wellmarked trails, the presence of reference points, among others, to complete the route" (Op cit., p. 4). In turn, the terrain conditions involve "aspects found on the route regarding the surface and the conditions to walk over it, such as types of surface, stretches with obstacles, with loose stones, among others" (Op cit., p. 5). And finally, the intensity of physical effort criterium is the "amount of physical effort required to complete the route, taking into account length and unevenness (uphills and descents), considering a common customer" (Op cit., p. 6).

All sections must be evaluated. The criteria are assigned a value on a scale of 1 to 5 , and all are applied to each trail for ranking. The highest value will represent the final value of the trail (Op cit., p. 8). 
The severity of the environment is established by observing these criteria. In the present study, the trails were considered little (55\%) and moderately (45\%) severe. Categorizing a trail as moderately severe happened mainly due to the analysis of the distance of the route, the presence of obstacles, and steep slopes.

The design of the trail consists of two basic elements: the first is the shape itself, which concerns the length and control points that determine its direction and flow; and the second refers to the format of the trail. "Their format can be classified as linear, circular, eight-shaped, contiguous rings, satellite rings and labyrinth-shaped" (ANDRADE, 2003, p. 247).

It was observed, in the PNMA, that all trails have a linear format, a type less suitable for protected natural areas, as it doubles the trampling (round trip), enhances the chance of encounters between hikers, and reduces the experience of contact with nature, what is, in general, searched by visitors (ABETA/MTUR, 2009). They are also more susceptible to physical erosion, caused by the action of rainwater and, therefore, need greater action of structural intervention and monitoring.

As for the environmental impacts, the curvilinear shape is preferable because, in its planning, it considers the contour lines, so that the natural drainage patterns are maintained. A good trail format enhances the visitation experience, as it suits groups of users based on their preferences (LECHNER, 2006, p. 45), e.g., cycle tourism and educational tourism.

As a central component of the recreation infrastructure for protected areas, many trail networks must accommodate an increasing diversity of visitors, activities, and modes of travel, and protect natural resources from visitor impacts (MARION; LEUNG, 2001, p. 36).

Trails should not be built directly along water bodies, as these are sensitive to impacts. However, in the PNMA, the Baú trail is located directly along the watercourse, requiring greater care in its management to avoid the impact on the quality and quantity of the water resources at the PA. In this case, the trail is more likely to suffer damage from soil compaction; siltation; and pollution by chemical and physical agents, dragged to the bed by rainwater by percolation processes.

It is important to keep paths well defined and signposted, to avoid accidents, disorientation of visitors, the opening of parallel roads and shortcuts, that result in forest loss and habitat fragmentation. One opportunity for environmental improvements is the implementation of interpretive trail programs. Nature interpretation trails are paths established with different shapes, lengths, and widths, which aim to bring visitors closer to the natural environment, or lead them to a specific attraction, enabling entertainment and education, through signs or interpretative resources (SALVATI, 2003). Thus, the PNMA trails are, in part, paths that require the identification of geographic 
accidents or cardinal points (54\%), which have signs indicating continuity $(27 \%)$ and which are well defined (19\%).

According to ICMBio (2018), the ideal is that PA trails have the following signs: entrance, route, destination, distance covered, educational/regulatory, interpretive, transit and emergency. At the PNMA, only two of the trails have route signs and distance-covered signs, those of Véu das Noivas and Poço do Baú. In the others, the signposting is insufficient or non-existent.

It is believed that the PNMA trails are informal, that is, they were created by visitors (MARION; LEUNG, 2011). Recently, the PA administration started the process of managing them, in a way recognized by outdoor activities entities (ALTA MONTANHA, 2019), however, the lack of specific training and inputs makes the process difficult and delayed, according to a study by Detoni and Fonseca Filho (2021), who identified the potential of trails and attractions for geotourism.

The PA management conducted minimal interventions to facilitate drainage on some trails, such as intercalated rock paving in infiltration areas and wetlands (Figure 2A), to reduce trampling and provide greater comfort for visitors; wooden bridges (Figure 2B), to reduce siltation of watercourses and even slippage and accidents; rustic route guidance signs (Figure 2C), to reduce deforestation and irregular opening of shortcuts; in addition to planting seedlings of endemic species for recovery of the riparian forest and restoration of the flow of spring areas.
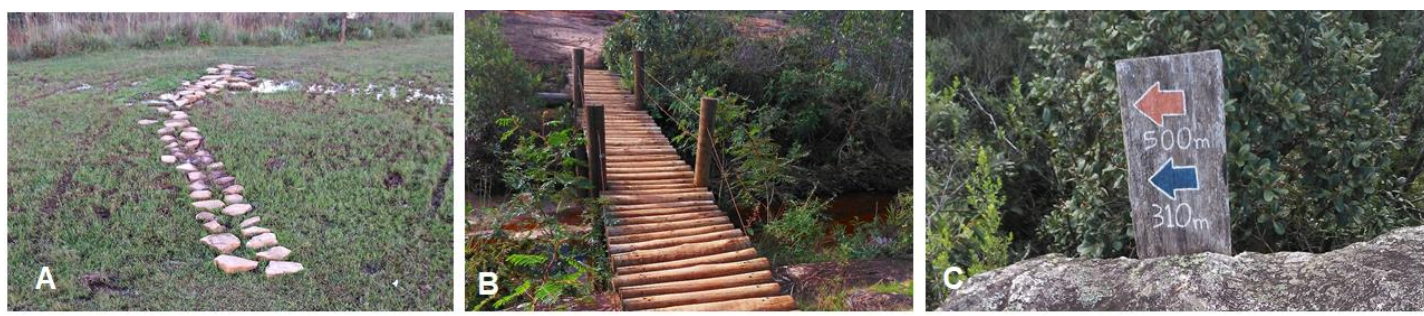

Figure 2: A) Rocky pavement in a marshy area at the Baú Trail; B) Wood bridge at the Cachoeira das Andorinhas Trail; C) Painted rustic wooden sign for the access to the Véu das Noivas Trail and the Baú Well.

Source: Simone Machado (2019).

Such initiatives, in preliminary areas, have already resulted in noticeable environmental improvements, such as reducing the opening of parallel trails/shortcuts, thus transmitting confidence from the public authority to tourists and the community, in addition to meeting the conservation goals for this type of PA. Alcântara (2007) highlights that the construction of bridges, water drainage channels, passages of rock blocks/tree trunks are alternatives to solve drainage correction problems, the crossing of water bodies, and erosion containment.

As for the conditions of the trails at the park, they are staggered or on uneven terrain $(41.6 \%)$, flat surfaces $(25 \%)$, paths with obstacles $(16.6 \%)$, 
and part of them requires the use of some type of vertical technique, with the common practice of abseiling and climbing (8,3\%).

The degree of difficulty of the trails, in turn, is, according to Guimarães and Mariano (2015), subjective. In addition to the conditions of the terrain itself (slope, substrate, and drainage), the difficulty to travel the path is individual, considering, for example, physical and weather conditions, luggage, etc.

In the case of the PNMA, the field analysis of the degree of intensity considered the perception of adults, non-athletes, and with light luggage, without chronic health problems or special physical limitations. The result was that most trails required little effort (54\%), while others were moderate $(46 \%)$.

For Lechner (2006), the elements of the trail, design, installations, and social characteristics can be related to the type of satisfaction that the visitor seeks to have. Thus, the access infrastructure enables recreational opportunities of the following types:

- Primitive: wild conditions, little direct management, almost no infrastructure development. Used for hiking, nature study, wildlife observation, climbing, among others. It has a low possibility of meeting other users, and little evidence of human intervention and indirect management. High probability of experiencing loneliness, proximity to nature, tranquility, independence, challenge, risk, and spirituality. The trails have a minimum structure to ensure the protection of resources, with 60 to $90 \mathrm{~cm}$ in width.

- Semi-primitive: it has characteristics similar to the primitive ones, however, they are slightly more signposted at the beginning and intersections.

- Natural: it allows the use of bicycles, cars, environmental education facilities, observatories, and it presents infrastructure that facilitates access, such as bridges, viewpoints, among others. Predominantly natural, with moderate evidence of human activity. There is a moderate interaction between users. The trails are wide, 60 to $120 \mathrm{~cm}$ wide, have direction and interpretation signs, access ramps, and bridges, as appropriate.

- Rural: it has visitor centers, hostels, and access to motor vehicles. It is a modified environment, with abundant evidence of the human presence and direct management. It allows a relatively high degree of social interaction, with conveniences and amenities, it can be asphalted or paved, with 60 to $250 \mathrm{~cm}$ of width.

- Urban: it allows the transit of large motor vehicles, such as buses. It has intense human activity and a high probability of interaction, the management occurs directly (Op cit., p. 2627). 
Applying this classification, it is considered that the state/environment of the trails at the park are semi-primitive (54\%), natural and rural (18\% each), and primitive (9\%). As for the type of terrain (soil or source material), it can be considered by the Management Plan (MYR, 2017) that they are clayey $(37.5 \%)$, sandy and with rocky outcrops (25\% each). For Lechner (2006), the composition of the terrain influences the susceptibility to compaction and erosion, in addition to internal drainage, carrying capacity, and the stability of slopes.

The results thus confirm the rich geotouristic potential identified in the PNMA (DETONI; FONSECA FILHO, 2021). Vieira and Cunha (2002, p. 1), in turn, highlight geomorphology as the base on which the landscape develops, conditioning the vegetation cover and many human activities, thus becoming a structuring factor for various landscapes. Mora Filho and Ruas (2008), on the other hand, report the importance of geomorphology for tourist studies, especially in areas with ecological trails, waterfalls, rapids, among others, where there is a large influx of tourists. Regarding ecotourism, for Morais et al. (2012), the main characteristics correspond to crossings, hiking, fauna/flora, and landscape observation.

Thus, environmental characteristics that represent elements of tourist interest were observed on the PNMA trails (Figure 3 ):

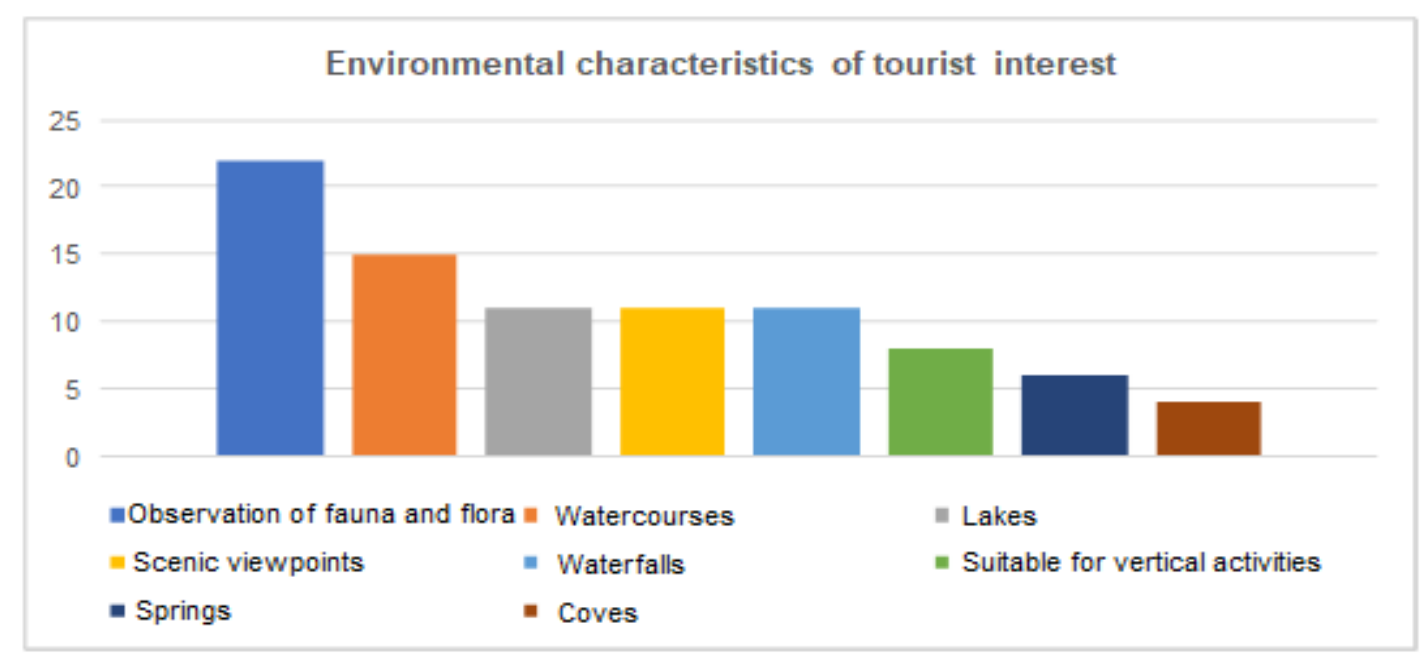

Figure 3: Graph of environmental characteristics of tourist interest in the Parque Natural Municipal das Andorinhas, Ouro Preto, Brazil. Source: research data (2019).

It is observed, in the previous graph, that the environmental attractions are mostly related to geodiversity (watercourses and reservoirs, viewpoints, waterfalls, springs, and caves) and, to a lesser extent, to biodiversity (observation of fauna and flora), corroborating the survey of the geotouristic potential of the park; by Detoni and Fonseca Filho (Op cit.), and of tourism demand, by Machado (2013); that the most popular attractions are waterfalls and viewpoints.

The main negative impacts observed on the trails were the presence of rubbish, abrasion, and graffiti on rocks; plants and rocks taken as souvenirs; remnants of bonfires; and noise pollution. Giatti (2004) highlights that the inadequate disposal of waste, in general, exposes the environment 
to contamination, offering risks to humans and animals, in addition to enabling the proliferation of pests and flies, similar to the results found by Rocha et al. (2020) on the Estudante Trail, in the Parque National da Tijuca (RJ); and by Pereira et al. (2019) in the Parque Estadual Mata do Pau-Ferrro (PB). In turn, Zannin and Sze (2003) identified, in the Parque Jardim Botânico in Curitiba (PR), that visitors point to noise pollution as a disturbance to visitation.

As for the relief in the trails, it was observed that they are strongly undulating $(67 \%)$, and, less frequently, steep (20\%), smooth-wavy (7\%), and flat $(6 \%)$. Although structures such as guardrails are important for the safety of visitors - at the Pedra do Jacaré scenic viewpoint, for example - the implementation of too much infrastructure may reduce the quality and perception of the environment (WILKES, 1977).

By understanding the dynamics of soils, it is possible to design structures to prevent landslides (LECHNER, 2006, p. 63), according to a study by Roncero-Siles (2003), who described the impacts of trails on vegetation as being direct, due to the mechanical damage caused by anthropic presence; and indirect, by changes in the physical and chemical properties of the soil, such as the increase in its compaction. Degradation can occur at two levels, superficial and deep. "On the surface, the area can be recovered naturally, however, when the degradation is deep, the environment does not recover naturally, requiring human interference" (RODRIGUES; GANDOLFI, 2001, p. 240), as noted in "the opening of cycling and motorcycling trails" (MYR, 2017, p. 566).

Regarding the degradation of the trails, it was possible to observe in the PNMA the occurrence of several sources/signs of it (Figure 4), by occurrence: forest fires/burnings (17.5\%); irregular opening of trails/deforestation (15\%); pasture, introduction of non-autochthonous species, presence of domestic animals, floral discontinuity (10\% each); plant extraction, fishing and noise pollution (7.5\% each); and temporary/permanent crops and mined area (2.5\% each). Considering deforestation and species evasion, Marcondes et al. (2020) also observed this impact on a proposed trail in the Parque Nacional da Serra da Canastra (MG).

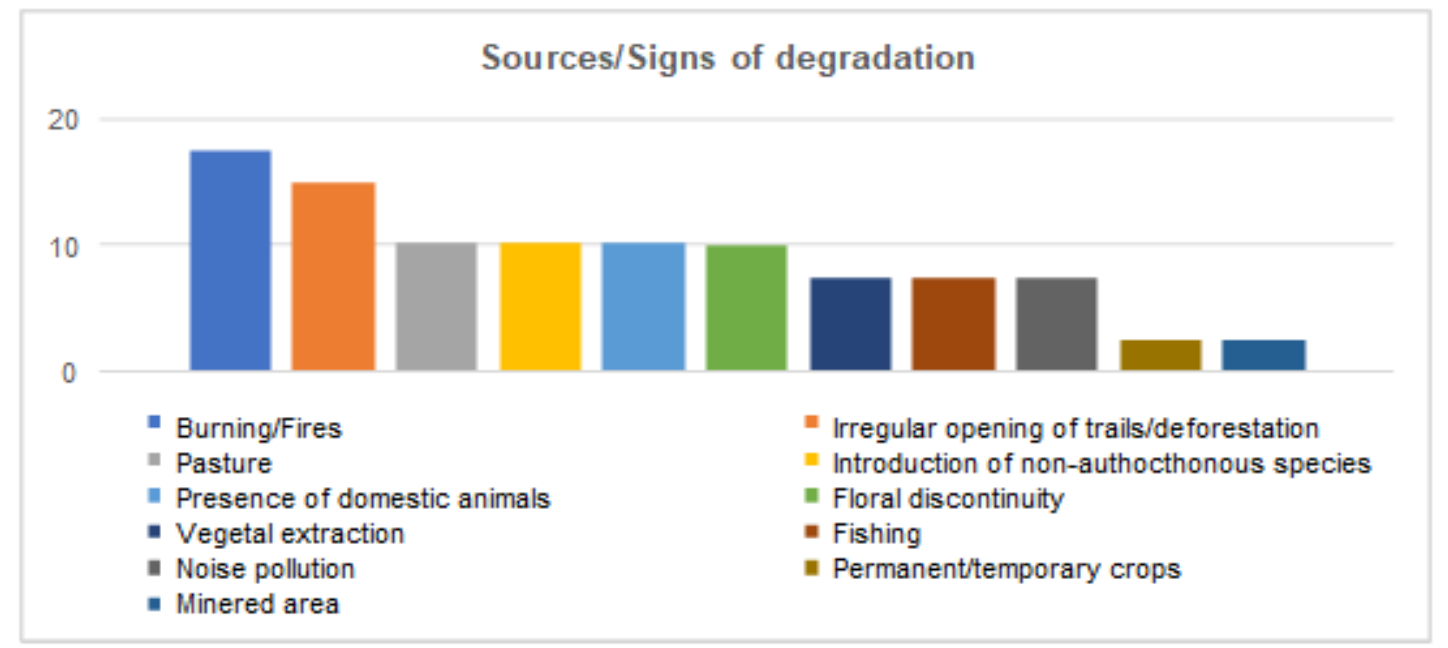

Figure 4: Graph of signs of degradation observed on the trails in the Parque Natural Municipal das Andorinhas, Ouro Preto, Brazil. Source: research data (2019). 
As for noise pollution, there was noise coming mainly from the surroundings, due to vehicular traffic on the access roads. According to the World Health Organization (WHO, 2012), after air and water pollution, noise pollution has increased in proportion, considered the biggest environmental problem affecting ecological environments, it results from the lack of control over the use of soil and a management plan; or non-compliance with it.

In turn, there are traces of economic activities in the PNMA, such as gold and quartzite mining, especially in the trails Véu da Noiva and Folhinha, respectively (MYR, 2017). Although they point to the material and immaterial cultural heritage for the archaeological value of artifacts and mining techniques (idem), the SNUC Law (BRASIL, 2000) does not allow activities in parks, prohibited by the General Rules for Public Use of the PNMA, and supervised by the managing organ.

Remnants of burnings were also observed (Figure 4A), and registration of the presence of domestic animals, such as horses grazing in the PA (Figure 4B). The first activity is allowed only in a controlled manner, to prevent and fight forest fires, and the second activity is completely prohibited by the SNUC Law.

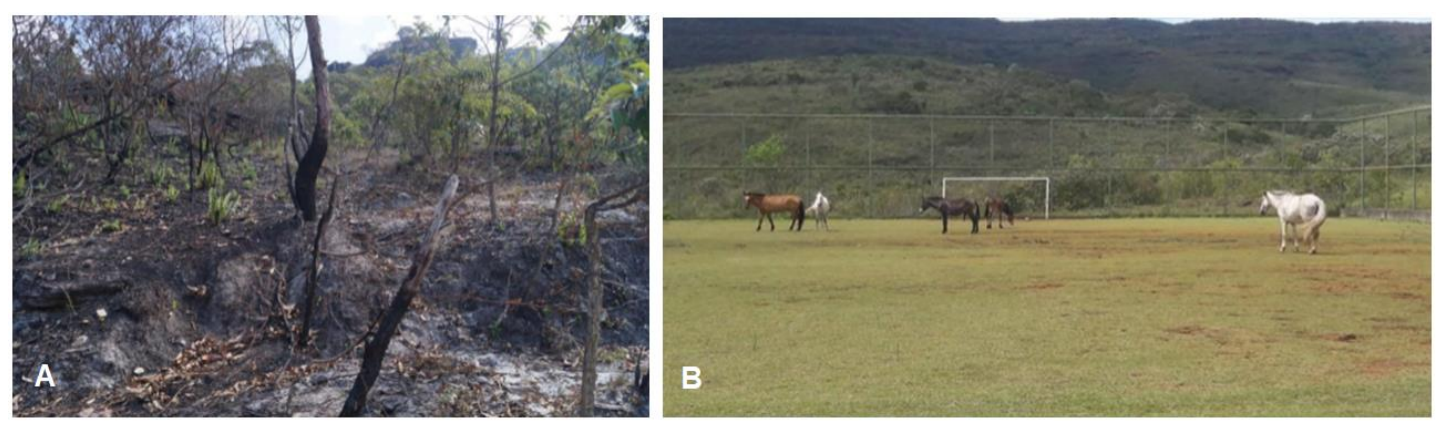

Figure 4: A) Photo of remnants of a forest fire near the trail; and B) domestic animals (horses) near the trails that start at the PNMA Visitor Center, Ouro Preto, Brazil.

Source: Myr (2017).

This fact is related to the presence of small rural properties, not expropriated in the $\mathrm{PA}$, a recurring land ownership problem in parks (ROCHA; DRUMOND; GANEN, 2010) - in addition to other PAs under public domain and ownership. According to the PNMA Management Plan (MYR, 2017, p. 129) "four situations of land disputes have already emerged", and part of the trails are on private properties, which are in the process of expropriation by the Municipality of Ouro Preto.

Also regarding the impacts on vegetation, it is noteworthy that:

Trampling produces a direct mechanical impact, resulting in exposure of tree roots, causing disease and falls, and a decrease in the capacity of air retention and water absorption, altering the capacity of the soil to support vegetal and the animal life associated with it (ANDRADE, 2003, p. 250). 
Ferreira et al. (2020) demonstrated the effects of trampling and erosion on two trails in the Ritápolis National Forest (MG); and Martinez et al. (2021) in the Parque Estadual do Rio Preto (MG), noting that there must be monitoring of the flora and soil in the trails.

Deforestation produces species loss, increases floral discontinuity, and can affect water circulation. In the case of the PNMA, this activity was registered in $15 \%$ of the trails. Such removal of vegetation is due to the opening of irregular roads and shortcuts aimed at the visitation and vegetal extraction of firewood, without the proper authorizations by competent organs from the surrounding community. Barcelos (2018) found that there was a reduction in the frequency of use of the trails by mammals, due to the increase in the intensity of tourists, in the Parque Nacional Cavernas do Peruaçu (MG).

The "fragmentation of the landscape, the dissection of natural environments by networks of trails, can affect wildlife and plants" (KNIGHT, 2000, p. 136). Some actions to recover degraded PPAs are essential. It is possible to mention, for example, the removal of degradation factors, such as the presence of cattle, agriculture, extractivism, etc.; soil correction; conducting natural regeneration (from the control of grasses that can compete with growing plants); induction of seed bank germination (by exposure to sunlight) and through seedlings, or seeds, causing densification (increase in the number of individuals), enrichment (increase in the variety of vegetables) and/or total planting when there is no means of regeneration (ATTANASIO, 2008).

In the PNMA, it was observed that most (44\%) of the soils have a sandy texture, being more suitable for the construction of trails; part of them is clayey and with compacted soil (22\% each), and thus less suitable for trails; and a smaller part (11\%) consists of rocks with graffiti and abrasions, that is, already impacted by the presence of visitors.

The best soils for the construction of trails are those welldrained, with moderate amounts of sand (drainage and strength), clay (a cementing agent) and a high content of organic matter; pure sands; fine or delicate soils; and those poorly drained (LECHNER, 2006, p. 40).

Sandy and large-particle soils are easily drainable, clayey and poorly drained soils are highly erodible; the silty ones and those with high organic matter contents are poorly drained and erodible. It is noteworthy that wet areas may indicate the presence of springs, water holes, and intermittent rivers, which require special attention (idem).

Soil density reflects the aggregation of particles and their aggregates. This increase causes compaction, which in turn results in lower rates of infiltration and susceptibility to erosion. The decrease in density is reflected in greater aggregation capacity, with an increase in porosity that favors water

511 Revista Brasileira de Ecoturismo, São Paulo, v 14, n.4, nov 2021-jan 2022, pp. 497-520. 
retention, root growth, gas exchange, and microbial activity (ALVARENGA; SOUZA, 1998, p. 205).

The use of trails for visitation activities can cause soil degradation (ANDRADE, 2005), hence the presence of ravines (33\%), erosion (25\%), pooling and weathering of rocks (16.6\% each), and landslide of slopes $(8 \%)$ on the trails in this park.

The process of soil erosion causes surface runoff to transport sediment from it to the rivers that drain the basin. These materials can immediately reach watercourses and, consequently, cause siltation of the bed and increase the potential for flooding. Among the immediate negative impacts caused by the increase in the concentration of sediments are, among others, the decrease in flow and silting, both observed in the PNMA (Figure 6). Structural measures to prevent and mitigate this impact include the construction of stabilization structures (slopes, berms, dams, water ladders, etc.), level distributors, and dissipating boxes.

Numerous anthropic activities introduce substances or physical characteristics into the environment that did not exist there before, or that were in different quantities. This process is called contamination (LEMOS, 2015). Of the impacts observed in watercourses located along the PNMA trails, there is the discharge of sanitary effluents (44\%); reports of decreased flow of water courses in the short, medium, and long term; engineering works that cause a rupture in rainwater infiltration; residential infrastructure and support equipment (22\% each); and silting/water reservoir (11\%).

In the PNMA, concerning the discharge of untreated sanitary effluents, inadequate conditions were registered in $44 \%$ of the watercourses located along the trails analyzed at the time of elaboration of the PA Management Plan. The analysis of the water samples from the Management Plan (MYR, 2017) - part of locations close to the trails studied here - showed appreciable quality conditions, except for point QA-01 (source of the Velhas river), where it was observed substantial impact associated with in natura waste, of sanitary origin.

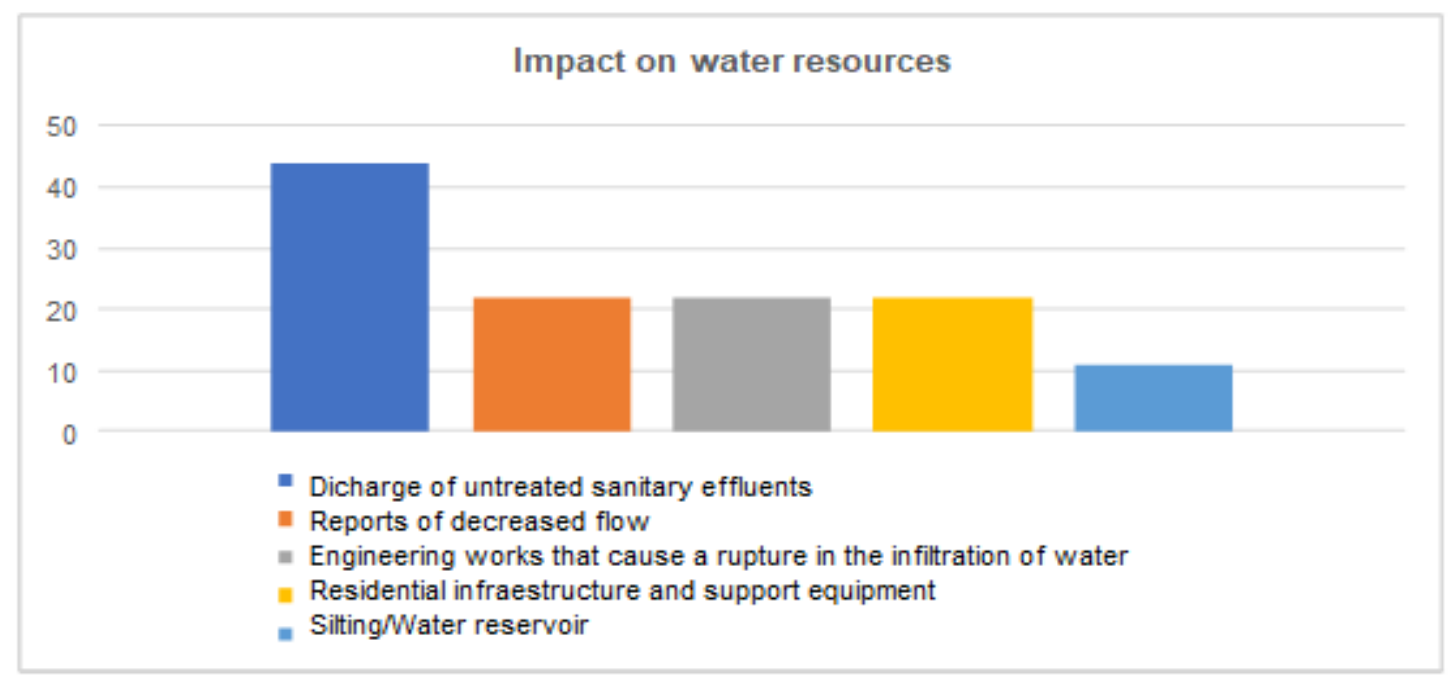

Figure 6: Graph of impacts on water resources near the trails in the Parque Natural Municipal das Andorinhas, Ouro Preto, Brazil. Source: research data (2019). 
As for the flow, still according to the Management Plan (MYR, 2017, p. 416), regarding the amount of water observed in the basin, it was found that it presents substantial water supplies, even in dry periods, especially when evaluating the minimum specific flow evidenced in the fluviometric support station (Água Limpa Downstream Station). However, residents in the vicinity informally reported, during fieldwork, that, for approximately 50 years, there has been a reduction in the flow of watercourses in the PNMA. This fact may be related to existing engineering works, such as the construction of Avenida das Andorinhas upstream, private residences not expropriated within the PNMA, and engineering works in the area of the PPA - such as the support structures, namely, management headquarters building and sports court.

Regarding the impacts on air quality, gas emissions from automobiles, smoke from barbecue grills, fires/wood stoves, and dust/particles on the roads were listed (18.18\% each). On $45 \%$ of the trails, no obvious air pollution was observed. Encouraging the use of low-impact alternative transport, such as bicycles, and the use of public transport may minimize this kind of pollution.

It is concluded that, if on the one hand, the PNMA has a considerable amount of trails in good condition with important characteristics for environmental interpretation (terrain conditions, length, infrastructure, and destination attractions), on the other hand, it suffers from environmental impacts (waste, fires, erosive processes, linear shape, lack of human resources). Although it demonstrates tourist potential to be developed through its trails, whose adaptations to ecotourism and geotourism increase their level of conservation and improve the visitor experience.

\section{Final considerations}

It was found that the PNMA trails, despite having pleasant natural characteristics appreciated by visitors, are environmentally unsustainable, lacking planning and periodic maintenance to minimize the negative impacts of their use in visiting activities.

The research enabled the identification of the main reasons for visitation; which is the observation of flora and fauna, and watercourses; and for degradation; fires, the irregular opening of trails, and deforestation; on the PNMA trails.

The study also supported the hypothesis that, when not planned and monitored, the use of trails may go against the conservationist and environmental sustainability principles of the PA.

It was also noted that the trails are being the target of planning, monitoring, and environmental recovery projects by the public authority managing the PA. Although incipient, the general picture of degradation has receded, which points to the visitation-conservation ambivalence, fulfilling part of the objectives of the PAs, especially of the Park type.

513 Revista Brasileira de Ecoturismo, São Paulo, v 14, n.4, nov 2021-jan 2022, pp. 497-520. 
As limitations, it is worth mentioning the non-correlation with data from interviews with visitors, community, and managers; in addition to not collecting and analyzing soil, water, and air samples; nor measuring impacts on the flora, among others - although data from other studies have been partially used, such as those from the Management Plan.

The efforts of this Plan are recognized in terms of indicators and targets for environmental education programs, with a focus on interpretive, guided trails with carrying capacity. However, it is recommended that permanent campaigns are performed to raise awareness on minimal impact visitation practices, such as managing the trails and sensitizing the surrounding community.

\section{Notes:}

1 The present work is the result of part of the results of the master's degree research project of the first author, guided by the co-authors.

\section{Aknowledgements:}

To the managers, monitors and visitors of the Parque Natural Municipal das Andorinhas for their collaboration. To the Municipality of Ouro Preto via the Municipal Secretariat for the Environment, for their support. To the Postgraduate Programs in Environmental Socioeconomic Sustainability (PPGSSA) and in Tourism and Heritage (PPGTURPATRI) at the Universidade Federal de Ouro Preto (UFOP), for the research. To the evaluators, editorial board of Revista Brasileira de Ecoturismo and to the proofreader/translator Luiz, for their contributions to the improvement of the article.

\section{References}

ABETA/MTUR. Diagnóstico do turismo de aventura no Brasil. Belo Horizonte: Associação Brasileira de Ecoturismo e Turismo de Aventura/Ministério do Turismo, 2009.

ABNT. NBR 10703. Define os termos empregados nos estudos, projetos, pesquisas e trabalhos em geral, relacionados à análise, ao controle e à prevenção da degradação do solo. Rio de Janeiro, Associação Brasileira de Normas Técnicas, 1989.

ABNT. NBR 15505-2: Turismo com atividades de caminhada - Parte 2: Classificação de percursos. Rio de Janeiro: Associação Brasileira de Normas Técnicas, 2008.

ALCÂNTARA, L. C. Trilhas interpretativas da natureza: planejamento, implantação e manejo. Monografia (Especialização em Turismo e Desenvolvimento Sustentável). Universidade de Brasília. Brasília. 2007. 
ALTA MONTANHA. O Parque das Andorinhas. 2019. Available at: $<$ https://altamontanha.com/o-parque-das-andorinhas/>. Access on Jul. $8^{\text {th }}$ 2021.

ALVARENGA, M. I. N.; SOUZA, J. A. Atributos do solo e o impacto ambiental. Lavras: Fundação de Apoio ao Ensino, pesquisa e extensão. Universidade Federal de Lavras, 1998.

ANDRADE, W. J. Implantação e manejo de trilhas. In: MITRAUD, S. (ed.). Manual de Ecoturismo de Base Comunitária: ferramentas para um manejo responsável. Brasília: Editora WWF Brasil, 2003. p. 247-259.

ATTANASIO, C. M. Manual técnico: restauração e monitoramento da mata ciliar e da reserva legal para a certificação agrícola - conservação da biodiversidade na cafeicultura. Piracicaba, SP: Imaflora, 2008.

BALMFORD, A. BERESFORD, J.; GREEN, J.; NAIDOO, R.; WALPOLE, M.; MANICA, A. A global perspective on trends in nature-based tourism. Plos Biology, v. 7, n. 6, p. e1000144, 2009.

BARCELOS, D. C. Efeitos da atividade turística sobre a fauna de mamíferos terrestres em um Parque Nacional brasileiro. Dissertação (Mestrado em Ecologia). Universidade de Brasília. Brasília. 2018.

BARROS, M. I. Caracterização da visitação, dos visitantes e avaliação dos impactos ecológicos e recreativos do planalto do Parque Nacional do Itatiaia. Dissertação (Mestrado em Engenharia Florestal). Universidade de São Paulo. Piracicaba (SP). 2003.

BRAGA, T. Pedestrianismo e percursos pedestres. Açores: Associação Ecológica. 2007.

BRASIL. Lei no. 4.771, de 15 de setembro de 1965. Institui o novo Código Florestal. Brasília: Instituto Brasileiro de Desenvolvimento Florestal, 1965.

BRASIL. Lei no $\mathbf{6 . 9 3 8}$, de 31 de agosto de 1981. Dispõe sobre a Política Nacional do Meio Ambiente, seus fins e mecanismos de formulação e aplicação, e dá outras providências. Brasília: Governo Federal, 1981.

BRASIL. Lei no. 9.985, de 18 de julho de 2000. Sistema Nacional de Unidades de Conservação da Natureza. Brasília: Ministério do Meio Ambiente, 2000.

CHRISTOFOLETTI, A. "A análise de bacias hidrográficas". In: CHRISTOFOLETTI, A. Geomorfologia. São Paulo: Edgard Blücher, EDUSP, 1974.

CHAPE, S.; SPALDING, M.; JENKINS, M. The world's protected areas: status, values in the 21 st century. San Diego: University of California Press, 2008.

CIFUENTES, M; IZURIETA, A; FARIA, H. H. Medición de la efectividad de manejo de áreas protegidas. Gland: WWF/ UICN, 2000.

COSTA, V. C.; TRIANE, B. P; COSTA, N. M. C. Impactos ambientais em trilhas: agricultura $\times$ Ecoturismo - um estudo de caso na Trilha do Quilombo (PEPB - RJ). Revista Brasileira de Ecoturismo, v. 1, n. 1, p. 84-113, 2008. 
DETONI, H.; FONSECA FILHO, R. E. Potencial do Parque Natural Municipal das Andorinhas, Ouro Preto (MG) para o Geoturismo. Turismo, Visão e Ação, v. 23, n. 2, p. 350-375, 2021.

DIAS, R. Turismo sustentável e meio ambiente. São Paulo: Atlas, 2012.

EISENLOHR, P. V.; MEYER, L.; MIRANDA, P. L. S.; REZENDE, V. L.;

SARMENTO, C.D.; MOTA, T.J.R.C.; GARCIA, L.C.; MELO, M.M.R.F. Trilhas e seu papel ecológico: o que temos aprendido e quais as perspectivas para a restauração de ecossistemas? Hoehnea, v. 40, n. 3, p. 407-418.

EMBRAPA. Manual de métodos de análise de solo. Rio de Janeiro: Empresa Brasileira de Pesquisa Agropecuária, 1997.

FERREIRA, A. C.; SALVIO, G. M. M.; VALLEJO, L. R.; FIGUEIREDO, M. do A. Indicadores geoecológicos como subsídio ao planejamento e uso de trilhas: estudo de caso das trilhas da Floresta Nacional de Ritápolis - Minas Gerais. Revista Eletrônica Uso Público em Unidades de Conservação, v. 8, n. 12, p. 27-38, 2020.

FERREIRA, L. V. et al. Áreas protegidas ou espaços ameaçados. Informe sobre o grau de implementação e vulnerabilidade das unidades de conservação brasileiras. Brasília: WWF, 1999.

GIATTI, L. L. Ecoturismo e impactos ambientais na região de Iporanga Vale do Ribeira. Tese (Doutorado em Saúde Pública). Universidade de São Paulo. São Paulo. 2004.

GIL, A.C. Métodos e técnicas de pesquisa social. 6. ed. São Paulo: Atlas, 2008.

GODOY, A. M. G. Ecodesenvolvimento - Evolução Histórica. 2009. Available

at:

$<$ http://amaliagodoy.blogspot.com/2007/09/ecodesenvolvimento-

histria.html>. Access on Jul. $8^{\text {th }} 2021$.

GUALTIERI-PINTO, L; OLIVEIRA, F. F.; ALMEIDA-ANDRADE, M.; PEDROSA, H. F.; SANTANA, W. A.; FIGUEIREDO, M. A. Atividade Erosiva em Trilhas de Unidades de Conservação: Estudo de Caso no Parque Nacional da Serra do Cipó, Minas Gerais, Brasil. Revista E-scientia, v. 1, n. 1, p. 1-16, 2008.

GUIMARÃES, S. T. Trilhas Interpretativas e Vivências na Natureza: Reconhecendo e reencontrando nossos eles com a paisagem. Anais do I Congresso Brasileiro de Planejamento e Manejo de Trilhas. Rio de Janeiro: UERJ, 2006.

GUIMARÃES, T. O.; MARIANO, G. Uso de Trilhas como Estratégia de Geoconservação. Anuário do Instituto de Geociências - UFRJ, v. 38, n. 1, p. $40-53,2015$.

IBGE. Manual técnico de pedologia. Brasília: Instituto Brasileiro de Geografia e Estatística, 2015.

IBGE. Vocabulário básico de recursos naturais e meio ambiente. Rio de Janeiro: Instituto brasileiro de Geografia e Estatística, 2004. 
ICMBio. Manual de sinalização de trilhas. Brasília: Instituto Chico Mendes de Conservação da Biodiversidade, 2018.

IEF. Zoneamento Ecológico da área de proteção ambiental estadual Cachoeira das Andorinhas, Ouro Preto, MG. Viçosa, MG: Instituto Estadual de Florestas/Universidade Federal de Viçosa, 2005.

KNIGHT, R. L. Forest fragmentation and outdoor recreation in the southern Rocky Mountains. In: KNIGHT, R. L.; SMITH, F. W.; ROMME, W. H.; BUSKIRK, S. W. (Eds.) Forest fragmentation in the Southern Rocky Mountains. Boulder, CO: University Press of Colorado. 2000. p.135-153.

KROEFF, L. L. Contribuição metodológica ao planejamento de trilhas ecoturísticas no Parque Nacional da Serra dos Orgãos (PARNASO), RJ. Dissertação (Mestrado em Geologia). Universidade Federal do Rio de Janeiro. Rio de Janeiro. 2010.

LAKATOS, Eva Maria. Fundamentos de metodologia científica. 5. ed. São Paulo: Atlas 2003.

LEUNG, Y. F.; MARION, J. L. Recreation impacts and management in wilderness: a state-of-knowledge review. USDA Forest Service Proceedings, v. 5, p.23-48, 2020.

LEUNG, Y. F.; PICKERING, C.; COLE, D. N. Informal trails and fragmentation effects: A conceptual and research overview. MMV, Stockholm, p. 358-359, 2012.

LECHNER, L. Planejamento, implantação e manejo de trilhas em Unidades de Conservação. Curitiba: Fundação Boticário de Proteção à Natureza, 2006.

LEMOS, P. (org.). Água e cultura: inventário de fontes de água da região de Ouro Preto. Ouro Preto: Livraria e Editora Graphar, 2015.

MACHADO, S. F. Caracterização dos visitantes e percepção de impacto ambiental em duas unidades de conservação de Ouro Preto - MG. 2013. Monografia (Bacharelado em Turismo). Escola de Direito, Turismo e Museologia - UFOP, Ouro Preto, 2013.

MAGRO, T. C. Impactos do uso público em uma trilha no planalto do Parque Nacional de Itatiaia. 1999. Tese (Doutorado em Engenharia Ambiental). Escola de Engenharia de São Carlos - USP, São Carlos, 1999.

MARCONDES, A. L. S., RIONDET-COSTA, D. R. T., MACHADO, G. O., FLORÊNCIO, G. W. L., ALVES, G. P., NEVES, J. A., SANTOS, K. B., GEJIMA JUNIOR, M. Y., FERNADES, N. B., DIAS PONS, N. A., BENASSI, R. B. Bioma Cerrado: fragilidades e potencialidades socioambientais de um projeto de trilha no Parque Nacional Serra da Canastra. Revista Brasileira de Geografia Física, v. 13, n. 6, 2978-2991, 2020.

MARION, J. L.; LEUNG, Y.-F. Indicators and protocols for monitoring impacts of formal and informal trails in protected areas. Journal of Tourism and Leisure Studies, v. 17, n. 2, p. 215-236, 2011. 
MARION, J. L.; LEUNG, Y.-F. Trail resource impacts and an examination of alternative assessment techniques. Journal of Park and Recreation Administration, v. 19, p. 17-37, 2001.

MARTINELLI, M.; PEDROTTI, F. A cartografia das unidades de paisagem: questões metodológicas. Revista do Departamento de Geografia, n. 14, p. 39-46, 2001.

MARTINEZ, J. H. I. A.; GONÇALVES, G. M.; OLIVEIRA, M. H. S.; CRUZ, E. $F$. Avaliação da vulnerabilidade à erosão das trilhas do Parque Estadual do Rio Preto - MG. In: H. PAPROCKI; J. H. I. A. MARTINEZ (Orgs.). Parque estadual do Rio Preto, geografia e diversidade. Curitiba: Appris, 2020.

MIKHAILOVA, I. Sustentabilidade: evolução dos conceitos teóricos e os problemas da mensuração prática. Revista Economia e Desenvolvimento, n. 16, p. 1-20, 2004.

MILARÉ, E. Direito do Ambiente: a gestão ambiental em foco. São Paulo: Editora Revista dos Tribunais, 2011.

MILLER, R. K. Planificación de Parques Nacional para el ecodesarrollo en América Latina. Madrid: Fundación para la Ecología y el Medio Ambiente, 1980.

MORA FILHO, P.S.; RUAS, L.M.S. As contribuições da geomorfologia ambiental no campo do turismo rural: a descrição paisagística como recurso metodológico para o planejamento turístico. Saber Acadêmico, n. 5, p. 4049, 2008.

MORAIS, F. M. et al. Ecoturismo em comunidades rurais: uma proposta para o desenvolvimento econômico, cultural e social na associação Barra do Saco, Codó - MA. Anais do VII CONNEPI - Congresso Norte Nordeste de Pesquisa e Inovação, Palmas (TO), 2012.

MYR. Plano de Manejo do Parque Natural Municipal das Andorinhas. Belo Horizonte: Myr Projetos Sustentáveis/CBH Rio das Velhas, 2017. Available at: $<$ https://cdn.agenciapeixevivo.org.br/arquivos/images/subcomites/projetos/pl anomanejo/145 DIAGNOSTICO PLANO MANEJO R26 170313.pdf>.

Access on Jul. $8^{\text {th }} 2021$.

NUNES, R. Análise dos aspectos geológicos-geotécnicos das rochas dos setores de escalada no Parque das Andorinhas em Ouro Preto - MG. Monografia (Graduação em Engenharia Geológica). Universidade Federal de Ouro Preto. Ouro Preto. 2021.

OLIVEIRA, E. Caderno técnico de percursos pedestres. Vila Nova de Cerveira, 2007.

OMS. Relatório de avaliação sobre as condições ambientais de saúde na Europa. 2012. Available at: <http://www.euro.who.int/en/healthtopics/environment-and-health/noise/data-and-statistics>. Access on Jul. $8^{\text {th }}$ 2021.

OMT. Introdução ao Turismo. Trad. Dolores Martins Rodriguez Córner. São Paulo: Organização Mundial de Turismo/Roca, 2001. 
OURO PRETO. Lei no 305, de 30 de dezembro de 1968. Dispõe sobre a criação de Parque. Ouro Preto: Câmara Municipal de Ouro Preto, 1968.

OURO PRETO. Lei no 69, de 21 de julho de 2005. Altera a Lei 305/68 que cria o Parque Municipal da Cachoeira das Andorinhas do município de Ouro Preto, acrescenta dispositivos e dá outras providências. Ouro Preto: Câmara Municipal de Ouro Preto, 2005.

PAIVA, A. C.; FRANÇA, T. L. Trilha interpretativas reconhecendo os elos com a Educação Física. Revista Brasileira de Ciências e Esporte, v. 28, n. 3, p. 109-124, 2007.

PEREIRA, T. F. CAMPOS, J. O.; PEREIRA, M. R. dos S.; LIMA, V. R. P. de. Ecoturismo e os impactos ambientais no Parque Estadual Mata do PauFerro, Areia, Paraíba. GEOTemas, v. 9, n. 1, p. 128-143, 2019.

PORTAL ANDORINHAS. Mapa. 2021. Available at: $<$ https://andorinhas.eco.br/acesse/>. Access on Jul. $8^{\text {th }} 2021$.

ROCHA, L. G. M.; DRUMMOND, J. A.; GANEM, R. S. Parques Nacionais Brasileiros: problemas fundiários e alternativas para a sua resolução. Revista Sociologia Política, v. 18, n. 36, p. 205-226, 2010.

ROCHA, M. B.; GOMES, S. B. V.; ROCHA, R. O.; PASSERI, M. G. Identificação de impactos ambientais relacionados à visitação pública no Parque Nacional da Tijuca: o caso da trilha do Estudante. Revista Tecnologia e Sociedade, v. 16, n. 39, p. 1-19, 2020.

RODRIGUES, R. R.; GANDOLFI, S. Conceitos, tendências e ações para recuperação de Florestas ciliares. In: RODRIGUES, R. R.; LEITÃO FILHO, R. F. Matas Ciliares: conservação e recuperação. 2 ed. São Paulo: Editora da Universidade de São Paulo: Fapesp, 2001. p. 235-247.

RONCERO-SILES, M.F. Modelagem espacial para atividades de visitação pública em áreas naturais. Dissertação (Mestrado em Geografia). Universidade de São Paulo. São Paulo. 2003.

RUSCHMANN, D. Turismo e planejamento sustentável: a proteção do meio ambiente. Campinas, SP: Papirus, 1997.

SALVATI, S. S. Trilhas: conceitos, técnicas de implantação e impactos. 2003. Available at: <http://ecosfera.sites.uol.com.br/trilhas.htm>. Access on Jul. $8^{\text {th }} 2021$.

SANTANA, A. Antropologia do Turismo: analogias, encontros e relações. São Paulo: Aleph, 2009.

SILVA, F. dos S. Os caminhos de Vila Rica no século XVIII: as rotas pela Serra de Ouro Preto. Monografia (Tecnólogo em Conservação e Restauro). Instituto Federal de Minas Gerais. Ouro Preto. 2016.

SILVA, G. G. L. da. Classificação do grau de dificuldade de trilhas: uso de geotecnologias na elaboração de um modelo aplicado no Parque Nacional do Itatiaia. Dissertação (Mestrado em Turismo). Universidade de São Paulo. São Paulo. 2016. 
SILVA, C.A; BOZELLI, R.L; FREIRE, L. Trilhas interpretativas: um estado da arte das pesquisas em educação ambiental. Anais do $\mathrm{V}$ Encontro Nacional de Ensino de Ciências da Saúde e do Ambiente Niterói/RJ, 2018.

TAKAHASHI. L. Y. Uso público em unidades de conservação. Curitiba: Fundação o Boticário de proteção à natureza, 2004.

VASCONCELOS, Diogo de. História antiga das Minas Gerais. Belo Horizonte: Editora Itatiaia Ltda, 1974.

VIEIRA, A.; CUNHA, L. A importância dos elementos geomorfológicos na valorização da paisagem: exemplos em morfologias cársica e granítica. Actas del IX Coloquio Ibérico de Geografia, Huelva, 2002.

WILKES, B. The myth of the non-consumptive user. The Canadian Field Naturalist, v. 91, n. 4, p. 343-349, 1997.

ZANNIN, P. H. T.; SZEREMETTA, B. Avaliação da poluição sonora no parque Jardim Botânico de Curitiba, Paraná, Brasil. Caderno de Saúde Pública, v. 19, n. 2, p. 683-686, 2003.

Simone Fernandes Machado: Universidade Federal de Ouro Preto, Ouro Preto, MG, Brasil.

E-mail: sissamachadofernan@gmail.com

Link to Lattes curriculum: http://lattes.cnpq.br/1523793003113053

Ricardo Eustáquio Fonseca Filho: Universidade Federal de Ouro Preto, Ouro Preto, MG, Brasil.

E-mail: ricardo.fonseca@ufop.edu.br

Link to Lattes curriculum: http://lattes.cnpq.br/1600424426811223

Sandra Maria Antunes Nogueira: Universidade Federal de Ouro Preto, Ouro Preto, MG, Brasil.

E-mail: sandra.nogueira@ufop.edu.br

Link to Lattes curriculum: http://lattes.cnpq.br/8257549728095056

Date of submission: August $4^{\text {th }} 2020$

Date of receiving and correctioins: June $22^{\text {th }} 2021$

Date of acceptance: June $22^{\text {th }} 2021$

Anonymously valued 